\title{
Business Intelligent Method For Academic Dashboard
}

\author{
Niki Destiandi ${ }^{1)^{*}}$, Aditiya Hermawan ${ }^{2)}$ \\ 1)2) Buddhi Dharma University \\ Tangerang, Indonesia \\ ${ }^{1)}$ niky.haiden89@gmail.com \\ 2)
}

\begin{abstract}
Article history:
Received 01 December 2018; Revised 4 December 2018;

Accepted 14 December 2018; Available online 19 December 2018

Keywords:

Business Intelligent Academic Dasboard KPI

Business Intelligent Life Cycle

Abstract

Business Intelligence Lifecycle is a method for developing effective business intelligence (BI) decision support applications such as the Academic Dashboard. There are six steps in the BI life cycle from the beginning to implementation such as Justification, Planning, Business Analysis, Design, Construction, and Deployment, where each step is developed to be more detailed in accordance with BI's environmental needs (L. T. Moss). Management of tertiary institutions in Indonesia requires appropriate and fast academic reports that make it possible to make strategic decisions and in order to improve the quality of education. Academic evaluations can be presented with the dashboard being easy for decision making. The dashboard is a page that displays graphics as a KPI from an organization and provides everything needed to make key research results [4]. Problems that occur there are a lot of academic data that is stored but when turning it into a report at the time of evaluation academic activities are difficult and require a long time and require monitoring, evaluation and measurement tools that can measure the performance of universities. The Business Intelligence Lifecycle can be used to provide information to produce high resolution by adding KPI components.
\end{abstract}

\section{INTRODUCTION}

Business Intelligence (BI) is a management term in business normally used in describing the applications and the technologies that are used in gathering, transforming and analyzing the data about an enterprise or concern in order to provide better decision making process [5]. Business Intelligence Lifecycle is a method for developing an effective business intelligence (BI) decision-support application such as Dashboard Academic. There are six steps in the BI lifecycle starting from beginning to implementation such as Justification, Planning, Business Analysis, Design, Construction, and Deployment which each step is developed to be more detailed according to the needs of BI environment [5].

Management of universities in Indonesia requires appropriate and fast academic reports that make it easier to make strategic decisions and in order to improve the quality of education. Requires a tool that can monitor, evaluate and measure performance in universities. The problem is that there is a large amount of stored academic data but to present it to the report when evaluating academic activities is difficult and requires a long time. Academic evaluation can be presented with a dashboard so that it becomes easy for decision making. A dashboard is a page that shows graphics as a KPI from an organization and provides all the important measurements needed to make the key to executive decision making [4].

College in Indonesia do reporting students, lecturers, and lecture activities data to PDDIKTI (Pangkalan Data Pendidikan Tinggi). PDDIKTI is a collection of data on the implementation of Higher Education in all universities that are nationally integrated and PDDIKTI is one of the instruments for implementing quality assurance [7]. PDDIKTI provide an application such as Feeder PDDIKTI which is used to manage Students data and data of each University's Lectur (User Guide Feeder). Problem that occur there is a lot of academic data stored but when transform it to a report at the time of academic activities evaluation becomes difficult and takes a long time and requires a monitoring, evaluating and measuring tools that can be measure performance of the college. 


\section{RELATED WORKS}

Business Intelligence Lifecycle mostly similar with engineering project or software-engineering project that is having six stages starting from the beginning to implementation such as Justification, Planning, Business Analysis, Design, Construction, and Deployment which each step is developed to be more detailed according to the needs of BI environment as illustrated in the following figure [5]:

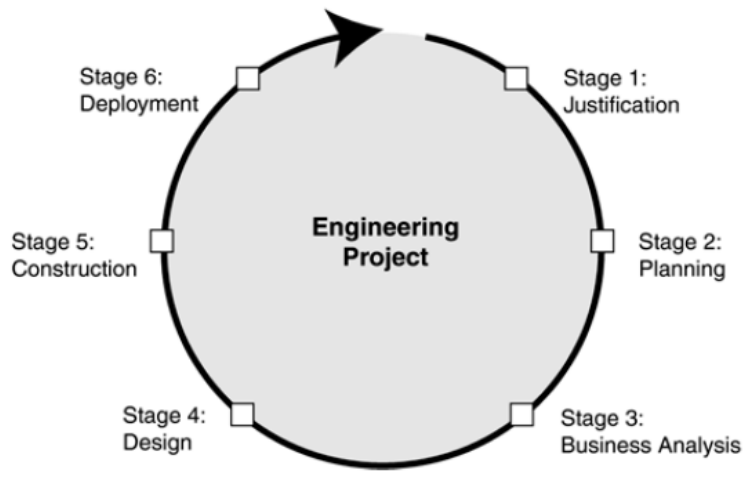

Figure 1 Engineering Project. [4]

In each stage, the steps are developed to be more detailed according to BI needs as illustrated in the following figure:

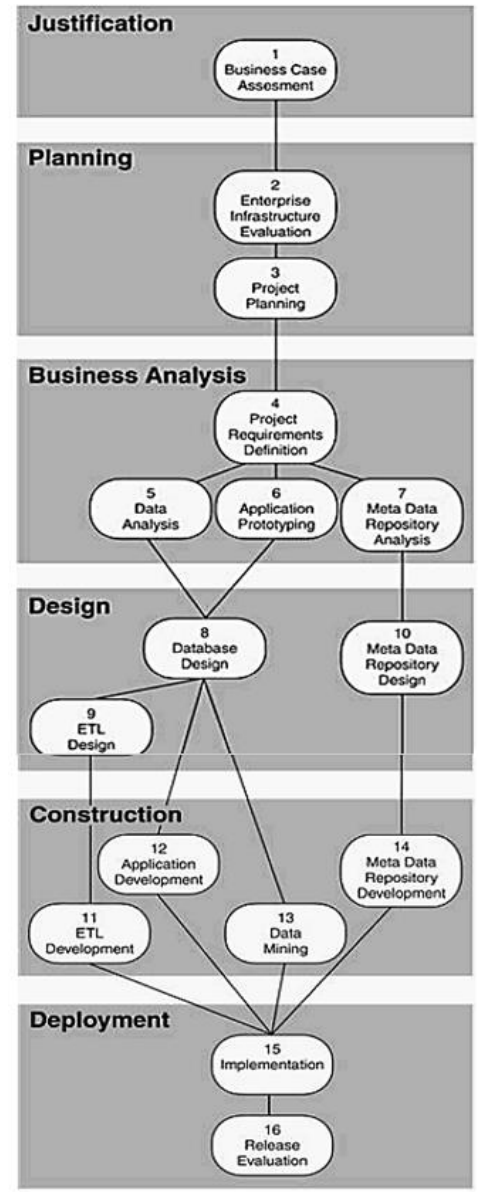

Figure 2 Business Intelligence Framework.[4] 
Explanation of each stage in the picture above is as follows:

1. Justification

This process is a business justification process by identifying the strategic business objectives of an organization and measuring profits such as profitability or organizational efficiency. BI applications must support the strategic objectives of the business. There are four components in the justification stage, namely:

a. Business Drivers: identify business strategic objectives, business driving factors such as vision and mission, then objective objectives of the BI application. Ensure that the BI application supports business strategic objectives.

b. Business analysis issues: analyze business problems and information needed to meet business strategic objectives by defining business information needs for high level management.

c. Cost-benefit analysis: estimate costs for building and maintaining the BI application. Calculate the tangible and intangible benefits obtained by the organization.

d. Risk assessment: assessing risks in terms of technology, complexity, integration, organization, project team, and financial investment.

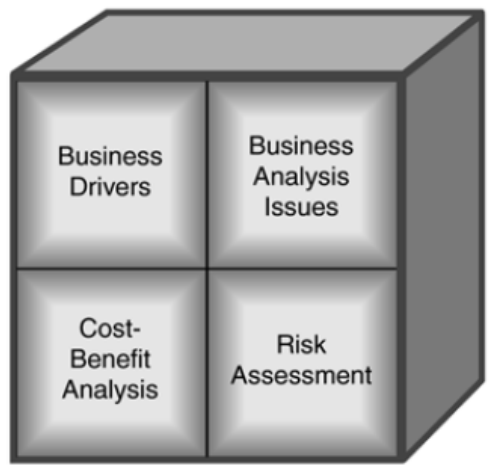

Figure 3. Justification Components.

2. Planning

Planning process related to BI infrastructure used and BI project development planning. Enterprise Infrastructure Evaluation or BI infrastructure planning includes two components, namely:

a. Technical infrastructure: includes hardware specifications, software, middleware, database management systems, operating systems, network components, meta data repositories, and utilities.

b. Non-technical infrastructure: includes meta data standards, meta data naming standards, development of logical models on company data, guidelines for conducting methodologies, testing procedures and procedures for solving problems with management.

3. Business Analysis

The process of analyzing business is divided into four components, namely:

a. Project Requirements Definition: conduct interviews with organizational executives to find out the information needs needed, to find out the problems in the organization that have not been answered and to find out the types of reports needed.

b. Data Analysis: perform data quality analysis, data availability, data type, and cardinality between data on source data used in BI projects.

c. Application Prototyping: builds the appearance of the user interface display and the type of report on the BI project to find out how far information needs can be conveyed. At this stage includes the tools used in building a BI project.

d. Meta Data Repositories Analysis: performs a needs analysis and analyzes the accessibility of the meta data contained in the source data used to display the report. Build a logical meta model or E$\mathrm{R}$ (Entity Relationship) model to find out the cardinality between meta data objects.

4. Design

The data architecture design process in the BI project is divided into three components, namely: 
a. Database Design: design a multidimensional database using star schema and snowflake schema, measure dimensions used for reporting, measure the depth of the query drill-down to display data in detail, choose the Database Management System (DBMS) that will be used.

b. Extract Transform Load Design: selection of tools used for the ETL process, preparing ETL processes that change different data source formats to be more common, checking unnecessary data redundancies and cleaning invalid data and designing ETL processes that adjusted to the data needs in the previous stage.

c. Meta Data Repository Design: architectural selection is centralized or decentralized in the meta data warehouse and design in the meta data warehouse using Entity-Relationship Design or Object-Oriented Design.

5. Construction

The BI project development phase is divided into four components, namely:

a. Extract Transform Load Development: application of the ETL process by using ETL tools that have been selected in the previous stage.

b. Application Development: the development of BI projects including reviewing the results of prototypes by recording the existing problems to then determine the final needs of a project and then building a script to display reports, queries to process data and design the user interface and test the program so as not to an error occurs when the application is implemented at this stage.

c. Data Mining: BI project implements data mining to complement the information needs of executives. This step involves testing algorithms, data mining techniques (data mining) such as clustering, prediction and organizing methods.

d. Meta Data Repository Development: the development of data access interfaces after a meta data warehouse is built that allows users to know information about business data in the BI database, statistical information from the ETL process that has been carried out and other processes related to meta data.

6. Deployment

a. Implementation: after the BI project is completed, it's time to implement it by holding training sessions for users, namely executives and preparing documentation and technical support.

b. Release Evaluation: after the BI project is implemented, the development team creates a final report which describes the performance and some parts that must be repaired or rebuilt.

\section{BUSINESS INTELLIGENCE LIFECYCLE}

The following step is the sequence of steps in the BI lifecycle method:

A. Justification

This stage explains at a glance information about PDDIKTI which become a driving factor in the development of BI applications and analyze the problems found such as college management needs a report that precise and fast which makes it easy to make strategic decisions and in order to improve the quality of education, requires a tool that can monitor, evaluate and measure performance in universities and there is a large amount of academic data stored but to present it in reports when evaluating academic activities becomes difficult and takes a long time. Also Risk Assessment that has been found is in the Feeder PDDIKTI there is no graph with measurement components such as KPI (Key Performance Indicator) so that is difficult to see information in order to making strategic decision process.

B. Planning

Planning process related to $\mathrm{BI}$ infrastructure that used and BI project development planning.

C. Business Analysis

The stage of determining KPI (Key Performance Indicator) as the basis for performance measurement in college and information needed by college management. This KPI is obtained from published journal reviews relating to academic activities contained in the Feeder PDDIKTI and refers to BAN-PT Undergraduate Accreditation Assessment (S1) Matrix with elements of assessment Standard 3 (Student and Graduates) and Standard 4 (Human Resources), analyzing the data source, i.e. data on the Feeder PDDIKTI and designing an application workflow with the use case diagram and activity diagram as well as designing the user interface by making a 
screen design also analyzing the meta data on the data source that is Feeder PDDIKTI. This Meta data is analyzed based on data analysis.

D. Design

The phase of multidimensional schema design in data mart using Star Schema. Star schema design based on the needs in the Project Requirement Definition and the data contained in this star schema design will be used to display reports. Extract Transform Load Design which is the phase of designing ETL (Extract Transform Load) process from data source into data mart. In this ETL design process, uses mapping data source tables to data mart tables. The tables selected in the data source, only those related to academic activities contained in the Feeder PDDIKTI only. Meta Data Repository Design is Architectural selection stage in the meta data warehouse and design the meta data warehouse using Entity-Relationship Design or Object-Oriented Design.

\section{E. Construction}

The implementation stage of the ETL process from the tables contained in the data source such as Feeder PDDIKTI into tables on data mart. Using PHP (PHP: Hypertext Prepocessor) script in performing ETL processes from Feeder PDDIKTI into data mart through intermediary web service. This ETL Development stage is a continuation of the ETL design stage. The Application development stage is carried out by development user interface display in which there are graphical reports and the testing phase of functionality in the application that has been built using the black box testing method. After the application development is complete, then proceed with the Release Evaluation stage using a Research Questionnaire to measure assessments of applications that have been built. Questionnaire questions are made based on aspects of information needed by the user, aspects of UI (User Interface) design, aspects of UX (User Experience) design and technical aspects.

\section{RESUlTS}

This section describes the results of each Business Intelligence Lifecycle process in making academic dashboards at higher education institutions:

A. Justification

Pangkalan Data Pendidikan Tinggi (PDDIKTI) is a data collection for the implementation of all Higher Education Higher Education that is nationally integrated. PDDIKTI is one of the instruments for implementing quality assurance. Management of higher education requires an appropriate and fast academic report that makes it easy to make strategic decisions and in order to improve the quality of education so that it requires a tool that can monitor, evaluate and measure performance in universities. There is a large amount of academic data stored but to present it to the report when evaluating academic activities is difficult and requires a long time. The lack of a PDDIKTI FEEDER does not yet have a graph with measurement components such as KPI (Key Performance Indicator), making it difficult when viewing information in the context of strategic decision making processes. 


\section{B. Planning}

Table 1 Planning

\begin{tabular}{|l|l|l|l|l|l|l|l|l|l|l|l|l|l|l|}
\hline \multicolumn{1}{|c|}{ Minggu } & $\mathbf{1}$ & $\mathbf{2}$ & $\mathbf{3}$ & $\mathbf{4}$ & $\mathbf{5}$ & $\mathbf{6}$ & $\mathbf{7}$ & $\mathbf{8}$ & $\mathbf{9}$ & $\mathbf{1 0}$ & $\mathbf{1 1}$ & $\mathbf{1 2}$ & $\mathbf{1 3}$ & $\mathbf{1 4}$ \\
\hline Identification Business Drivers & & & & & & & & & & & & & \\
\hline $\begin{array}{l}\text { Identification Business } \\
\text { Analysis Issues }\end{array}$ \\
\hline $\begin{array}{l}\text { Project Requirement } \\
\text { Definition }\end{array}$ & & & & & & & & & & & \\
\hline Data Analysis & & & & & & & & & & & & & \\
\hline Application Prototyping & & & & & & & & & & & & & \\
\hline $\begin{array}{l}\text { Meta Data Repository } \\
\text { Analysis }\end{array}$ & & & & & & & & & & & & & \\
\hline Database Design & & & & & & & & & & & & & \\
\hline ETL Design & & & & & & & & & & & & \\
\hline Meta Data Repository Design & & & & & & & & & & & & & \\
\hline ETL Developtment & & & & & & & & & & & \\
\hline Application Developtment & & & & & & & & & & & & \\
\hline Implementation & & & & & & & & & & & & \\
\hline Release Evaluation & & & & & & & & & & & & & \\
\hline
\end{tabular}

C. Business Analysis

- Project Requirements Definition

At this stage the KPI (Key Performance Indicator) was established as a basis for measuring performance in universities. The KPI is obtained from a review of published journals related to academic activities contained in the PDDIKTI FEEDER and refers to the BAN-PT Undergraduate Accreditation Assessment Matrix (S1) with assessment elements Standard 3 (Students and Graduates) and Standard 4 (Human Resources) (Buku VI) [1], The following is a KPI table that has been summarized:

Table 2 KPI for Dasbord Academic

\begin{tabular}{|c|c|c|}
\hline No. & KPI & Sub KPI \\
\hline 1. & $\begin{array}{l}\text { New Student Transfer Ratio: New Students Not } \\
\text { Transfer. }\end{array}$ & - \\
\hline \multirow[b]{2}{*}{2.} & \multirow{2}{*}{$\begin{array}{l}\text { Quality of Student Graduates in each } \\
\text { Department. }\end{array}$} & Average GPA of Graduates in each Department \\
\hline & & Average Study Period Graduates in each Department. \\
\hline 3. & Overall Quality of Student Graduates. & $\begin{array}{l}\text { Total Quality Score of Graduates in each Department } \\
\text { is divided by the number of Departments. }\end{array}$ \\
\hline 4. & Qualifications of Lecturers in each Department. & - \\
\hline 5. & Qualifications of Lecturers at the University. & $\begin{array}{l}\text { The Total Score of Permanent Lecturer Adequacy } \\
\text { and Qualification in each Department is divided by } \\
\text { the number of Department s. }\end{array}$ \\
\hline 6. & Ratio of Interested Students: Capacity & - \\
\hline 7. & $\begin{array}{l}\text { Ratio of Number of Graduates of the Specific } \\
\text { Force: Number of new Students of the Force }\end{array}$ & - \\
\hline 8. & $\begin{array}{l}\text { Ratio of Number of Students Drop Out: Number } \\
\text { of New Students }\end{array}$ & - \\
\hline 9. & Percentage of Active Students & - \\
\hline
\end{tabular}


- Data Analysis

At this stage, an analysis of source data is carried out, namely data on the PDDIKTI FEEDER, here is information about the table structure and table relationships that exist in the PDDIKTI FEEDER:

Table 3 Struktur Table FEEDER PDDIKTI.

\begin{tabular}{|l|l|l|}
\hline Table Name & \multicolumn{1}{|c|}{ Field } & \multicolumn{1}{|c|}{ Data Type } \\
\hline Kuliah_mahasiswa & id_smt & Varchar(5) \\
\hline & id_reg_pd & Varchar(45) \\
\hline & id_stat_mhs & CHAR(2) \\
\hline & Ips & Decimal(5,2) \\
\hline & sks_smt & Decimal(5,2) \\
\hline & Ipk & Decimal(5,2) \\
\hline & sks_total & Decimal(5,2) \\
\hline & nm_lemb & Varchar(45) \\
\hline & mulai_smt & Varchar(5) \\
\hline & Nipd & Varchar(45) \\
\hline & nm_stat_mhs & Varchar(15) \\
\hline & nm_smt & Varchar(25) \\
\hline & nm_pd & Varchar(45) \\
\hline & Nisn & Int(11) \\
\hline & Jk & Enum('L','P') \\
\hline & id_agama & Int(2) \\
\hline & tmpt_lahir & Varchar(25) \\
\hline & tgl_lahir & Date \\
\hline
\end{tabular}

In terms of data quality, data sourced from FEEDER PDDIKTI is valid, because every college that reports to PDDIKTI through the PDDIKTI FEEDER application must meet the standards set by PDDIKTI. In terms of data availability, all information on user needs based on KPI that has been summarized can be fulfilled because the KPI that has been summarized relates to academic activities contained in the PDDIKTI FEEDER.

\section{- Application Prototyping}

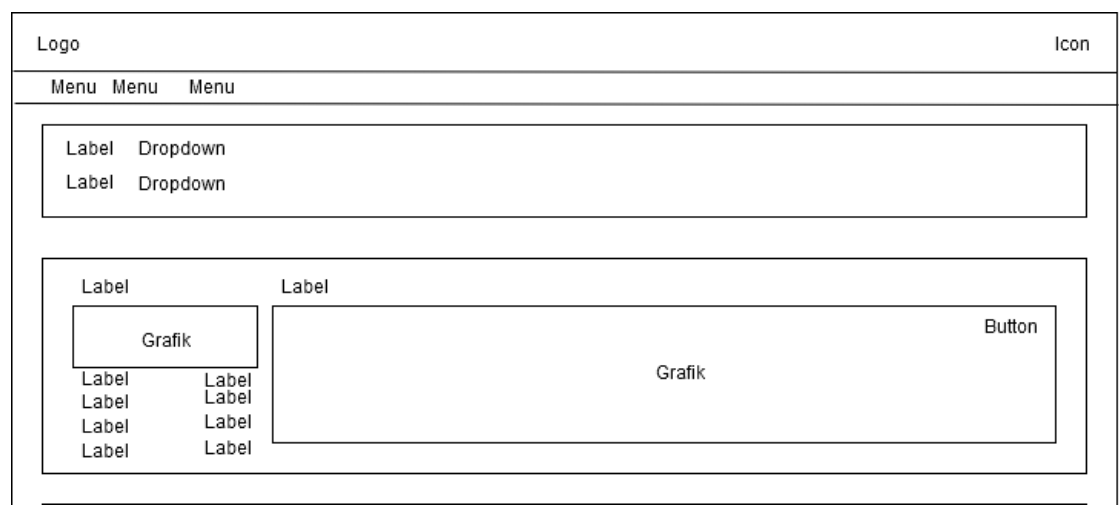

Figure 4. Prototype

- Meta Data Repositories Analysis

Table 4 Meta Data Tabel FEEDER PDDIKTI.

\begin{tabular}{|c|c|c|c|}
\hline Table Name & Primary_key & Foreign_key & Description \\
\hline kuliah_mahasiswa & - & $\begin{array}{l}\text { id_smt, } \\
\text { id_reg_pd, } \\
\text { id_stat_mhs, } \\
\text { id_agama. }\end{array}$ & $\begin{array}{l}\text { Tabel aktivitas } \\
\text { perkuliahan } \\
\text { mahasiswa. }\end{array}$ \\
\hline
\end{tabular}




\section{Design}

- Database Design

The stage of designing a multidimensional scheme using Star Schema.

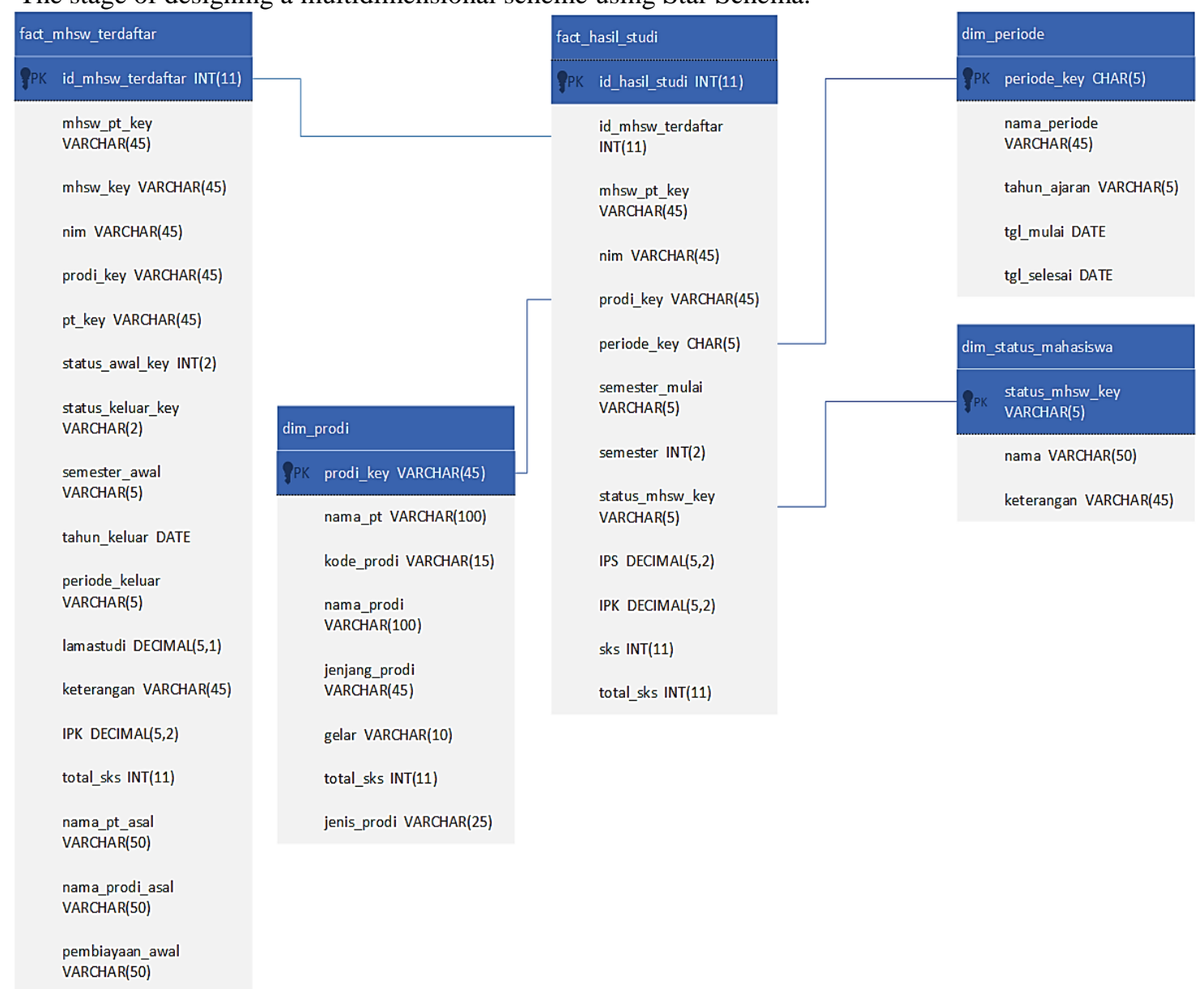

Figure 5 Star Schema Study Results.

\section{- Extract Transform Load Design}

Extract Transform Load (ETL) Design by mapping (mapping) the columns contained in the PDDIKTI FEEDER table to the columns contained in the destination table (fact tables \& dimension tables in the data mart). Here are some ETL design mappings:

Table 5 Mapping ETL tabel fact_hasil_studi.

\begin{tabular}{|c|c|c|c|c|}
\hline \multicolumn{2}{|r|}{ source table } & \multirow{2}{*}{ To } & \multicolumn{2}{|c|}{ Target table } \\
\hline Tabel & Kolom & & Tabel & Kolom \\
\hline \multirow{11}{*}{ kulliah_mahasiswa } & id_smt & $->$ & \multirow{11}{*}{ fact_hasil_studi } & periode_key \\
\hline & id_stat_mhs & $->$ & & status_mhsw_key \\
\hline & ips & $->$ & & IPS \\
\hline & sks_smt & $->$ & & sks \\
\hline & ipk & $->$ & & IPK \\
\hline & sks_total & $->$ & & total_sks \\
\hline & mulai_smt & $->$ & & semester_mulai \\
\hline & semester (hasil agregasi kolom id_smt - mulai_smt) & $->$ & & semester \\
\hline & nipd & $->$ & & $\mathrm{nim}$ \\
\hline & id_reg_pd & $->$ & & mhsw_pt_key \\
\hline & id_sms (Hasil Join Tabel mahasiswa_pt) & $->$ & & prodi_key \\
\hline
\end{tabular}




\section{E. Construction}

- Extract Transform Load Developtment

The stage of applying the ETL process (Extract Transform Load) from the tables contained in the data source is FEEDER PDDIKTI into the target table in the data mart. This stage is a continuation of the ETL Design stage in sub-chapter 3.4.2. The author uses a PHP script (PHP: Hypertext Prepocessor) in performing ETL processes from FEEDER PDDIKTI into the data mart through a web service intermediary. Following is the process of applying ETL which is divided into 15 processes according to the ETL design process:

- Application Developtment

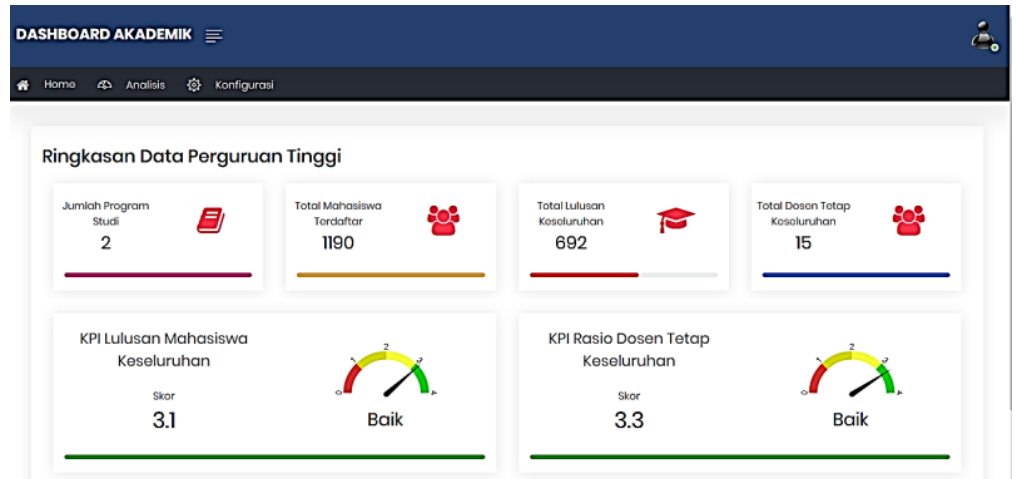

Figure 6. Dashboard

On this page there is a summary of tertiary education data in the form of a total number of study programs, total students enrolled in tertiary institutions, total graduates and total permanent lecturers as well as a gauge graph showing KPI (Key Performance Indicator) Student Graduates and Overall Lecturer Ratio where detailed information on KPI above can be seen on the Lecturer Analysis menu and Analysis of Students and Graduates.

\section{CONCLUSIONS}

Academic dashboard modeling using the Business Intelligence Lifecycle can be used as a reference in providing information for strategic decision making in higher education by adding a KPI component (Key Performance Indicator) that refers to the BAN-PT Undergraduate Accreditation Assessment Matrix (S1) with Standard 3 rating elements (Students \& Graduates) and Standard 4 (Human Resources) that collect data on the PDDIKTI FEEDER. The dashboard can be implemented as the implementation of higher quality assurance.

The data source for the academic dashboard that was built only came from FEEDER PDDIKTI which had no other external sources and could not be integrated directly with the system in the university.

\section{REFERENCES}

[1] Buku VI. Matriks Penilaian Instrumen Akreditasi Program Studi Sarjana. (2008). Jakarta: Badan Akreditasi Nasional Perguruan Tinggi.

[2] Inmon, W. H. (2005). Building Data Warehouse, 4th Edition. Canada: John Wiley \& Sons, Inc.

[3] Kimball, R., \& Ross, M. (2013). The Data Warehouse Toolkit 3rd Edition. Indianapolis: John Wiley \& Sons, Inc.

[4] Laudon, K. C., \& Laudon, J. P. (2014). Management Information Systems - Managing The Digital Firm 13th Edition. Harlow: Pearson Education.

[5] L. T. Moss and S. Atre, Business Intelligence Roadmap: The Complete Project Lifecycle for Decision Support Applications, Canada: Addison-Wesley, 2004.

[6] Parmenter, D. (2010). KEY PERFORMANCE INDICATORS Developing, Implementing, and Using Winning KPIs, 2nd Ed. Canada: Wiley.

[7] User Guide Feeder PDDIKTI - Sistem Informasi Manajemen Akademik Modul Pangkalan Data Perguruan Tinggi, vol. 1, Jakarta: PDDIKTI - Kementrian Riset, Teknologi dan Pendidikan Tinggi Republik Indonesia. Direktorat Jenderal Pendidikan Tinggi, pp. 1-10.

[8] V. S. Akshaya and T. Purusothaman, "Business Intelligence as a Service in Analysis of Academic Courses," International Journal of Applied Engineering Research, vol. 2, no. 4, pp. 2458-2467, 2016. 